\title{
Fodinicurvata sediminis gen. nov., sp. nov. and Fodinicurvata fenggangensis sp. nov., poly- $\beta$ - hydroxybutyrate-producing bacteria in the family Rhodospirillaceae
}

\author{
Correspondence \\ Xiao-Long Cui \\ xlcuiynu@yahoo.com.cn or \\ xlcui@ynu.edu.cn
}

\author{
Yong-Xia Wang, ${ }^{1} \dagger$ Ji-Hui Liu, ${ }^{1}+$ Xiao-Xia Zhang, ${ }^{2}$ Yi-Guang Chen, ${ }^{1,3}$ \\ Zhi-Gang Wang, ${ }^{1}$ Yun Chen, ${ }^{1}$ Oin-Yuan Li, ${ }^{1}$ Oian Peng $^{1}$ and Xiao-Long Cui ${ }^{1}$ \\ ${ }^{1}$ Yunnan Institute of Microbiology, Yunnan University, Kunming, Yunnan 650091, PR China \\ ${ }^{2}$ Agricultural Cultural Collection of China, Institute of Agricultural Resources and Regional Planning, \\ Chinese Academy of Agricultural Sciences, Beijing 100080, PR China \\ ${ }^{3}$ College of Bio-resources and Environmental Science, Jishou University, Jishou, Hunan 416000, \\ PR China
}

Two Gram-negatively stained, facultatively anaerobic, non-motile, vibrioid and rod-shaped, chemoheterotrophic bacterial strains, designated YIM D82 $^{\top}$ and $\mathrm{YIM} \mathrm{D812}^{\top}$, were isolated from a salt mine in Yunnan, south-west China. DNA-DNA hybridization, genomic DNA G + C content and phylogenetic analyses based on 16S rRNA gene sequences divided the two isolates into two distinct genospecies that were also clearly differentiated by fatty acid profiles, carbon source utilization patterns, antibiotic susceptibility and biochemical characteristics. The two isolates grew in the presence of $1.5-20 \% \mathrm{NaCl}$, and optimally at $28{ }^{\circ} \mathrm{C}$ and $\mathrm{pH} 7.5$. The genomic DNA G $+\mathrm{C}$ contents of strains $\mathrm{YIM} \mathrm{D}^{\top} 2^{\top}$ and $\mathrm{YIM} \mathrm{D} 12^{\top}$ were 61.5 and $62.3 \mathrm{~mol} \%$, respectively.

Phylogenetic analyses based on 16S rRNA gene sequences indicated that strains $\mathrm{YIM} \mathrm{D}^{\top} 2^{\top}$ and YIM D812 ${ }^{\top}$ were members of the family Rhodospirillaceae and showed 90.5-90.6\% and 90.1$90.2 \%$ similarities with their closest relatives, Rhodovibrio sodomensis and Rhodovibrio salinarum, respectively. Differential phenotypic and genotypic characteristics of the two isolates from recognized genera showed that the two strains should be classified as representing a new genus and two novel species for which the names Fodinicurvata sediminis gen. nov., sp. nov. (type strain YIM D82 ${ }^{\top}=\mathrm{DSM} 21159^{\top}=\mathrm{KCTC} 22351^{\top}$ ) and Fodinicurvata fenggangensis sp. nov. (type strain YIM D812 ${ }^{\top}=$ CCTCC AA $208037^{\top}=$ DSM $21160^{\top}$ ) are proposed.
The family Rhodospirillaceae, belonging to the order Rhodospirillales (Pfennig \& Trüper, 1971) of the class Alphaproteobacteria, comprises 21 genera (http://www. bacterio.cict.fr). During the course of a study of the microbial diversity of the Fenggang salt mine in Yunnan, south-west China, two cream-white-pigmented bacterial strains, designated YIM D82 ${ }^{\mathrm{T}}$ and YIM D812 ${ }^{\mathrm{T}}$, were isolated. The aim of the present study was to determine the exact taxonomic positions of strains YIM D82 ${ }^{\mathrm{T}}$ and

†These authors contributed equally to this work.

Abbreviation: $\mathrm{PHB}$, poly- $\beta$-hydroxybutyrate.

The GenBank/EMBL/DDBJ accession numbers for the 16S rRNA gene sequences of strains YIM D82 ${ }^{\top}$ and YIM D812 $^{\top}$ are FJ357426 and FJ357427, respectively.

Two-dimensional thin-layer chromatograms of the polar lipids of strains YIM D82 ${ }^{\top}$ and YIM D812 ${ }^{\top}$ and a table showing the cellular fatty acid contents of strains YIM D82 ${ }^{\top}$ and YIM D812 ${ }^{\top}$ are available as supplementary material with the online version of this paper.
YIM D812 ${ }^{\mathrm{T}}$ by using a polyphasic approach that included the analysis of phenotypic properties, detailed phylogenetic analysis based on 16S rRNA gene sequences and DNADNA relatedness.

Strains YIM D82 ${ }^{\mathrm{T}}$ and YIM D812 ${ }^{\mathrm{T}}$ were isolated from a sediment sample collected from the salt mine by using a standard dilution-plating technique at $28{ }^{\circ} \mathrm{C}$ on Difco marine agar 2216 (MA; pH 7.2), supplemented with $3 \%$ $(\mathrm{w} / \mathrm{v}) \mathrm{NaCl}$. Pure cultures were maintained on nutrient agar (NA; Difco) supplemented with $5 \% \mathrm{NaCl}$, and stored as $20 \%(\mathrm{v} / \mathrm{v})$ glycerol suspensions at $-80{ }^{\circ} \mathrm{C}$.

Gram staining was performed using the method of Magee et al. (1975) with crystal violet (60 s), iodine mordant (60 s), $95 \%$ ethanol (5-10 s) and safranin counterstain (60 s), and with the $3 \% \mathrm{KOH}$ lysis test (Gregersen, 1978) as a supplementary test to Gram staining. Cellular morphology and motility were examined by using light microscopy (model BH 2; Olympus). Growth at various 
concentrations of salt was determined on NA supplemented with $\mathrm{NaCl}$ at $0,0.5,1,1.5,2,2.5,3,5,7,10,12,15,20$, 25 and $30 \%(\mathrm{w} / \mathrm{v})$. Growth at various $\mathrm{pH}$ values (4-11, in increments of $0.5 \mathrm{pH}$ units) and temperatures $(4,10,15$, $20,25,28,37,42,45,50,55$ and $60{ }^{\circ} \mathrm{C}$ ) were determined on the maintenance medium (NA supplemented with $5 \%$ $\mathrm{NaCl}$ ). Growth under anaerobic conditions was determined after incubation in an anaerobic chamber (GasPak Anaerobic system; BBL) on NA supplemented with $5 \%$ $\mathrm{NaCl}$ with or without nitrate. Accumulation of poly- $\beta$ hydroxybutyrate (PHB) was observed by using both negatively stained electron microscopy and Sudan black staining (Smibert \& Krieg, 1994) under a light microscope. Bacteriochlorophyll $a$ was analysed spectrophotometrically according to the procedure of Cohen-Bazire et al. (1957) following the recommendations of Allgaier et al. (2003). Catalase and oxidase activities were determined using $3 \%$ $(\mathrm{v} / \mathrm{v})$ hydrogen peroxide and Kovacs' reagent (Kovacs, 1956), respectively. L-Phenylalanine deamination was examined using the method of Richard \& Kiredjian (1995). Citrate utilization was tested on Simmons' citrate agar (Sigma). $\mathrm{H}_{2} \mathrm{~S}$ production was determined on Kligler iron agar (Difco). Methyl red and Voges-Proskauer tests were performed as described by Smibert \& Krieg (1994). Nitrate reduction, hydrolysis of aesculin and gelatin, acid production from glucose, indole production, arginine dihydrolase, urease and $\beta$-galactosidase were tested using an API 20NE kit (bioMérieux), according to the manufacturer's instructions. Other enzyme activities were assayed by using an API ZYM kit (bioMérieux), except that the bacterial suspensions were prepared in autoclaved $5 \% \mathrm{NaCl}$ solution. Carbon utilization was tested using artificial seawater medium (Cho \& Giovannoni, 2006) as the basal medium with each carbon source at a final concentration of $0.5 \%(\mathrm{w} / \mathrm{v}$ or $\mathrm{v} / \mathrm{v})$. Antibiotic resistance was determined with the disc diffusion method using commercial antibiotic-impregnated discs (BBL Becton Dickinson). The results were estimated according to the formation of the inhibition zone.

Isoprenoid quinones were extracted by using the method of Collins et al. (1977) and analysed by HPLC as described by Tamaoka et al. (1983). Polar lipids were extracted according to the procedures described by Minnikin et al. (1984) and were identified by using two-dimensional TLC after spraying with the appropriate detection reagents (Collins \& Jones, 1980). The presence of phosphatidylcholine was identified by spraying with Dragendorff reagent (Sigma). Biomass for quantitative fatty acid analysis of the two strains was prepared by scraping growth from NA supplemented with $5 \% \mathrm{NaCl}$ that had been incubated for 5 days at $28{ }^{\circ} \mathrm{C}$. Analysis of the cellular fatty acid profiles followed the method described by Sasser (1990) using the Microbial Identification System (MIDI). The G+C content of the genomic DNA was determined by using HPLC according to Mesbah et al. (1989), after extraction of DNA using the method of Cui et al. (2001). The genomic DNA of Escherichia coli DH5 $\alpha$ was used as a standard.
The 16S rRNA gene was amplified and sequenced as described by Cui et al. (2001). The sequence was compared to those available in GenBank using BLAST (Altschul et al., 1990). Alignments and similarities were obtained using CLUSTAL_X. Phylogenetic analyses were carried out using MEGA3 (Kumar et al., 2004). Distances (corrected according to the Kimura two-parameter model; Kimura, 1980) were calculated and clustering was performed with the neighbour-joining method (Saitou \& Nei, 1987). A maximumlikelihood (Felsenstein, 1981) tree (not shown) was generated using the treeing algorithm contained in the PHYLIP package (Felsenstein, 1993). Bootstrap analysis was used to evaluate the tree topology of the neighbour-joining data by means of 1000 resamplings (Felsenstein, 1985).

Strains YIM D82 ${ }^{\mathrm{T}}$ and YIM D812 ${ }^{\mathrm{T}}$ were both facultatively anaerobic, Gram-negative and non-motile. Cells were vibrioid and rod-shaped. PHB granules were detected in the two strains by using both negatively stained electron microscopy and Sudan black staining. Neither flagella nor endospores were observed. Colonies were cream-white, circular, convex and opaque with irregular margins after growth on NA supplemented with $5 \%$ at $28{ }^{\circ} \mathrm{C}$ for 5 days. Growth occurred under anaerobic conditions. The temperature range for growth was $15-42{ }^{\circ} \mathrm{C}$ (optimum, $28{ }^{\circ} \mathrm{C}$ ) and the $\mathrm{pH}$ range for growth was 6.5-8.5 (optimum, 7.5). Growth occurred at $\mathrm{NaCl}$ concentrations of $1.5-20 \%(\mathrm{w} / \mathrm{v})$ (optimum, 5\%). The two strains were catalase- and oxidase-positive. They were negative for Methyl red and Voges-Proskauer reactions. The two strains did not produce $\mathrm{H}_{2} \mathrm{~S}$ or L-phenylalanine deaminase. Biochemical tests for nitrate reduction, arginine dihydrolase and urease were positive. Hydrolysis of aesculin and gelatin, indole production, glucose acidification, and phenylalanine deaminase and $\beta$-galactosidase were negative. Acetone/methanol-extractable pigments and bacteriochlorophyll $a$ were not produced. Therefore, the energy metabolism of the two strains appeared to be exclusively non-photosynthetic chemoheterotrophy. Major characteristics that differentiate the two strains are given in Table 1. Carbon source utilization patterns and antibiotic susceptibility are given in the species descriptions.

The major cellular fatty acids of strain YIM $\mathrm{D} 82^{\mathrm{T}}$ comprised $\mathrm{C}_{18: 1} \omega 7 c(48.6 \%), \mathrm{C}_{18: 1} 2-\mathrm{OH}(12.2 \%)$ and $\mathrm{C}_{16: 0}(11.8 \%)$, and those of strain YIM D812 ${ }^{\mathrm{T}}$ comprised $\mathrm{C}_{18: 1} \omega 7 c(46.6 \%), \mathrm{C}_{18: 1} \quad 2-\mathrm{OH} \quad(14.7 \%)$ and $\mathrm{C}_{16: 0}$ $(10.6 \%)$ (see Supplementary Table S1, available in IJSEM Online). The fatty acid $\mathrm{C}_{18: 1} \omega 7 c$ was commonly found as a major component in both strains YIM D82 ${ }^{\mathrm{T}}$ and YIM $\mathrm{D} 812^{\mathrm{T}}$, which is a feature shared by members of the class Alphaproteobacteria (Labrenz et al., 2000). However, moderate amounts of $\mathrm{C}_{18: 1} 2-\mathrm{OH}(12.2-14.7 \%)$ and $\mathrm{C}_{19: 0}$ cyclo $\omega 8 c(7.9-7.4 \%)$ were found in strains YIM $\mathrm{D} 82^{\mathrm{T}}$ and YIM D812 ${ }^{\mathrm{T}}$, but were not found at significant levels in the genus Rhodovibrio. In addition, the presence of fatty acids iso- $\mathrm{C}_{15: 0} \mathrm{G}, \mathrm{C}_{18: 1} \omega 9 c$ and $\mathrm{C}_{20: 2} \omega 6,9 c$ clearly differentiated the two novel isolates from the genera Rhodovibrio, Azospirillum, Tistrella, Inquilinus and 
Table 1. Characteristics that differentiate strains $Y I M D 82^{\top}$ and YIM D812 ${ }^{\top}$ from other phylogenetically related genera in the family Rhodospirillaceae

Taxa: 1, strain YIM D82 ${ }^{\mathrm{T}}$ (Fodinicurvata sediminus gen. nov., sp. nov.); 2, strain YIM D812 ${ }^{\mathrm{T}}$ (Fodinicurvata fenggangensis sp. nov.); 3, Rhodovibrio (data from Nissen \& Dundas, 1984; Mack et al., 1993; Imhoff et al., 1998; Garrity et al., 2005); 4, Azospirillum (Tarrand et al., 1978; Reinhold et al., 1987; Khammas et al., 1989; Sly \& Stackebrandt, 1999; Eckert et al., 2001; Xie \& Yokota, 2005; Peng et al., 2006; Mehnaz et al., 2007a, b; Young et al., 2008); 5, Rhodocista (Favinger et al., 1989; Kawasaki et al., 1992; Imhoff et al., 1998; Zhang et al., 2003); 6, Defluviicoccus (Maszenan et al., 2005); 7, Tistrella (Shi et al., 2002); 8, Skermanella (Sly \& Stackebrandt, 1999); 9, Inquilinus (Coenye et al., 2002); 10, Thalassobaculum (Zhang et al., 2008). +, Positive; w, weakly positive; -, negative; $\mathrm{v}$, variable; NA, not available. All strains are Gram-negative and catalase-positive (data for catalase were not available for the genera Rhodocista and Rhodovibrio).

\begin{tabular}{|c|c|c|c|c|c|c|c|c|c|c|}
\hline Characteristic & 1 & 2 & 3 & 4 & 5 & 6 & 7 & 8 & 9 & 10 \\
\hline Habitat & $\begin{array}{l}\text { Deposit of } \\
\text { salt mine }\end{array}$ & $\begin{array}{l}\text { Deposit of } \\
\text { salt mine }\end{array}$ & $\begin{array}{c}\text { Seawater, ponds } \\
\text { of solar salt }\end{array}$ & $\begin{array}{l}\text { Soil, root, } \\
\text { fresh water }\end{array}$ & $\begin{array}{l}\text { Freshwater, } \\
\text { wastewater }\end{array}$ & Sludge & Wastewater & Lake water & $\begin{array}{l}\text { Cystic fibrosis } \\
\text { patients }\end{array}$ & Coastal seawater \\
\hline Colony colour & Cream-white & Cream-white & Pink, red & Pink, white & Red, pink & Beige & NA & Apricot & Pink & Cream-yellow \\
\hline $\begin{array}{l}\text { Cell size }(\text { width } \times \\
\text { length; } \mu \mathrm{m})\end{array}$ & $\begin{array}{c}0.3-0.5 \times 0.7- \\
1.5\end{array}$ & $\begin{array}{c}0.2-0.4 \times 0.5- \\
1.3\end{array}$ & $\begin{array}{c}0.6-0.9 \times 1.0- \\
3.5\end{array}$ & $0.6-0.9 \times 2-30$ & $1-2 \times 3.0$ & $1.5-4.5$ & $0.7-1.0$ (width) & $1-1.5 \times 2-3$ & $\mathrm{NA}$ & $0.3-0.5 \times 1.3-1.5$ \\
\hline Cell shape & $\begin{array}{c}\text { Rod and } \\
\text { vibrioid }\end{array}$ & Rod and vibrioid & $\begin{array}{l}\text { Vibrioid, } \\
\text { spiral }\end{array}$ & $\begin{array}{l}\text { Plump, vibrioid } \\
\text { straight rod }\end{array}$ & $\begin{array}{l}\text { Vibrioid, } \\
\text { spiral }\end{array}$ & Coccus & Rod & Rod & Rod & $\begin{array}{l}\text { Slightly curved } \\
\text { and straight rod }\end{array}$ \\
\hline Flagella $^{*}$ & - & - & $\mathrm{MP}, \mathrm{BP}$ & V & MP & - & MP & MP & NA & MP \\
\hline Temperature range $\left({ }^{\circ} \mathrm{C}\right)$ & $15-42$ & $15-42$ & $20-47$ & $4-41$ & $25-47$ & $20-30$ & $20-40$ & $10-37$ & $25-42$ & $10-35$ \\
\hline $\mathrm{pH}$ range & $6.5-8.5$ & $6.5-8.5$ & $7-8$ & $5-8.5$ & $5.7-8$ & $5-8.5$ & $5-9$ & NA & NA & $7-9$ \\
\hline $\begin{array}{l}\mathrm{NaCl} / \text { salt tolerance } \\
(\%, w / v)\end{array}$ & $1.5-20$ & $1.5-20$ & $3-24$ & $<5$ & NA & NA & $<1$ & $<5$ & $<6$ & $1-10$ \\
\hline Poly- $\beta$-hydroxybutyrate & + & + & + & $\mathrm{v}$ & + & + & + & + & NA & + \\
\hline Bacteriochlorophyll $a$ & - & - & + & - & + & $\mathrm{NA}$ & - & - & $\mathrm{NA}$ & - \\
\hline Oxidase & + & + & NA & + & NA & - & + & + & $\mathrm{v}$ & + \\
\hline Gelatinase & + & + & NA & $\mathrm{v}$ & $\mathrm{NA}$ & $\mathrm{w}$ & + & - & $\mathrm{v}$ & + \\
\hline \multicolumn{11}{|c|}{ Utilization of carbon sources } \\
\hline L-Arabinose & + & - & NA & $\mathrm{v}$ & NA & + & + & + & - & + \\
\hline D-Glucose & + & + & - & $\mathrm{v}$ & - & + & NA & + & - & - \\
\hline Citrate & + & + & - & $\mathrm{v}$ & - & NA & $\mathrm{NA}$ & + & - & - \\
\hline myo-Inositol & - & + & NA & v & NA & $\mathrm{NA}$ & $\mathrm{NA}$ & - & - & - \\
\hline D-Mannitol & + & - & - & $\mathrm{v}$ & - & $\mathrm{NA}$ & + & + & - & - \\
\hline L-Rhamnose & - & - & NA & $\mathrm{v}$ & $\mathrm{NA}$ & $\mathrm{NA}$ & $\mathrm{NA}$ & + & - & - \\
\hline D-Ribose & - & - & NA & $\mathrm{v}$ & NA & $\mathrm{NA}$ & $\mathrm{NA}$ & + & NA & + \\
\hline Sucrose & + & - & - & V & - & $\mathrm{NA}$ & $\mathrm{NA}$ & NA & - & + \\
\hline Major quinone & Q-10 & Q-10 & Q-10, MK-10 & Q-10 & Q-9 & $\mathrm{NA}$ & Q-10 & Q-10 & NA & Q-10 \\
\hline $\begin{array}{l}\text { DNA G }+\mathrm{C} \text { content } \\
(\mathrm{mol} \%)\end{array}$ & 61.5 & 62.3 & $66.2-68.1$ & $64-71$ & $68.3-69.9$ & 66 & 67.5 & 67.2 & 70.9 & 68.0 \\
\hline
\end{tabular}

${ }^{\star}$ BP, Bipolar; MP, monopolar. 
Thalassobaculum. Therefore, the fatty acid profiles of strains YIM D82 ${ }^{\mathrm{T}}$ and YIM D812 ${ }^{\mathrm{T}}$ differed distinctly from those of related genera in the family Rhodospirillaceae. Furthermore, strains YIM D82 ${ }^{\mathrm{T}}$ and YIM D812 ${ }^{\mathrm{T}}$ could be clearly differentiated by means of the presence or absence of $\mathrm{C}_{13: 0} 2-\mathrm{OH}, \mathrm{C}_{14: 1} \omega 5 c$, anteiso- $\mathrm{C}_{15: 0}, \mathrm{C}_{16: 0} 2-\mathrm{OH}$ and $\mathrm{C}_{17: 1} \omega 7 c$. The isoprenoid quinone in strains YIM D82 and YIM D812 ${ }^{\mathrm{T}}$ was ubiquinone $10(\mathrm{Q}-10)$, which was also found in the genera Azospirillum, Tistrella, Skermanella and Thalassobaculum. However, MK-10 and Q-9 were also found, respectively, in the genera Rhodovibrio and Rhodocista (Table 1). The polar lipids consisted of diphosphatidylglycerol, phosphatidylmethylethanolamine and phosphatidylcholine, except that strain YIM D812 ${ }^{\mathrm{T}}$ also contained phosphatidylinositol and three unknown phospholipids, and strain YIM D82 ${ }^{\mathrm{T}}$ contained one unknown phospholipid (see Supplementary Fig. S1, available in IJSEM Online). The $\mathrm{G}+\mathrm{C}$ contents of the genomic DNA of strains YIM D82 ${ }^{\mathrm{T}}$ and YIM D812 ${ }^{\mathrm{T}}$ were 61.5 and $62.3 \mathrm{~mol} \%$, respectively.

Phylogenetic analysis of almost-complete $16 \mathrm{~S}$ rRNA gene sequences of strains YIM D82 ${ }^{\mathrm{T}}$ and YIM D812 ${ }^{\mathrm{T}}$ revealed that they formed a distinct lineage within the family Rhodospirillaceae (Fig. 1). The similarity between the $16 \mathrm{~S}$ rRNA gene sequences of the two strains was $98.2 \%$. Species of the genus Rhodovibrio were found to be the nearest phylogenetic neighbours; this relationship was supported by a high bootstrap value ( $92 \%)$ and also by the other treemaking algorithm used. The levels of $16 \mathrm{~S}$ rRNA gene sequence similarities between strain YIM $\mathrm{D} 82^{\mathrm{T}}$ and the type strains of Rhodovibrio sodomensis and Rhodovibrio salinarum were 90.6 and $90.5 \%$, respectively, and 85.0$89.5 \%$ to the other type species of the family Rhodospirillaceae. The levels of $16 \mathrm{~S}$ rRNA gene sequence similarities between strain YIM D812 ${ }^{\mathrm{T}}$ and the type strains of $R$. sodomensis and R. salinarum were 90.2 and $90.1 \%$, respectively, and $84.3-88.1 \%$ to the other type species of the family Rhodospirillaceae. The low sequence similarity values between strains YIM D82 ${ }^{\mathrm{T}}$ and YIM D812 ${ }^{\mathrm{T}}$ and the type species of genera of the family Rhodospirillaceae demonstrated that the two strains represent a distinct genus in the family Rhodospirillaceae.

DNA-DNA hybridization was performed using the photobiotin-labelling method of Ezaki et al. (1989), with a multiwell plate reader (CytoFluor; PerSeptive Biosystems). The DNADNA relatedness between strains YIM D82 ${ }^{\mathrm{T}}$ and YIM D812 was $27.5 \%$. Therefore, strains YIM D82 ${ }^{\mathrm{T}}$ and YIM D812 should be considered as representing two separate species.

The data obtained based on the polyphasic approach used, such as fatty acid profiles, quinone and $16 \mathrm{~S}$ rRNA gene phylogenetic analyses, demonstrated conclusively that strains YIM D82 ${ }^{\mathrm{T}}$ and YIM D812 ${ }^{\mathrm{T}}$ should be recognized as representing a novel genus within the family Rhodospirillaceae. In addition, the DNA-DNA hybridization values, polar lipid patterns and differences in phenotypic traits indicated that the two strains represent two novel species in the new genus, for which the names Fodinicurvata sediminis gen. nov., sp. nov. and Fodinicurvata fenggangensis sp. nov. are proposed.

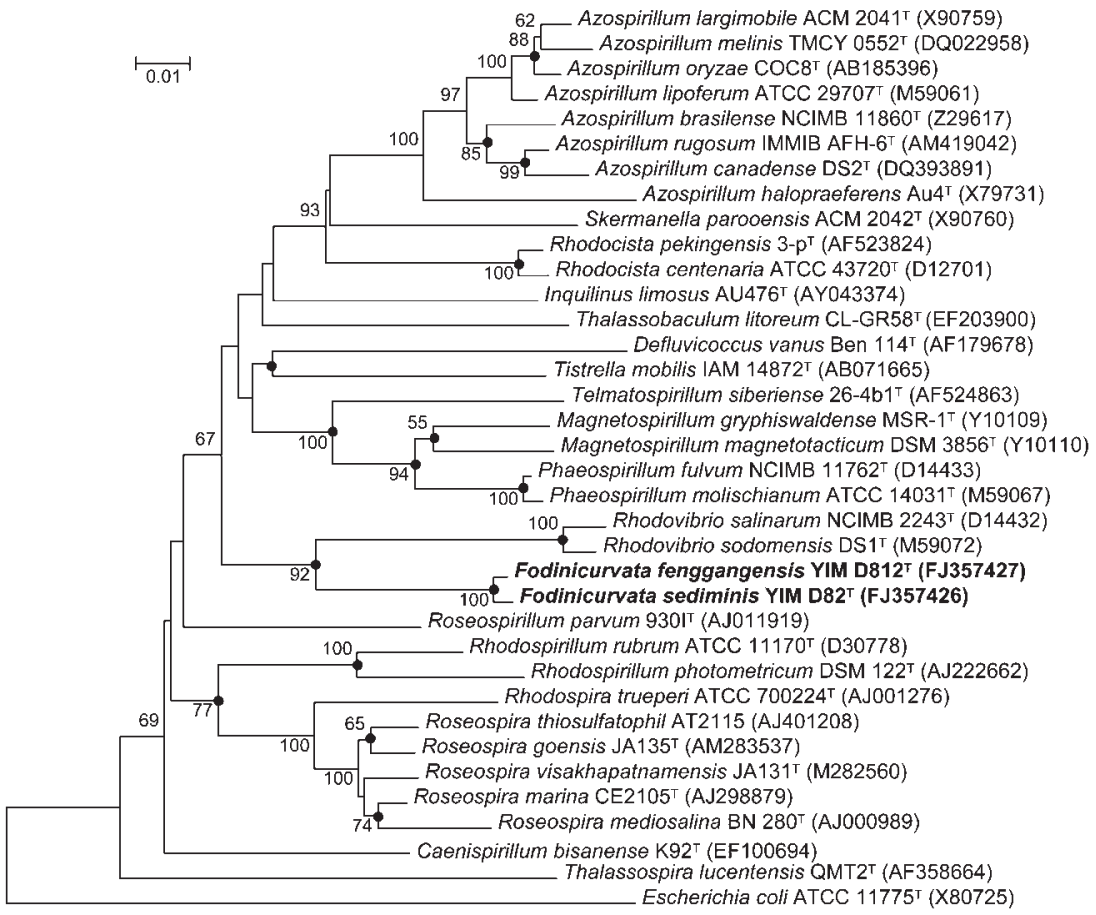

Fig. 1. Neighbour-joining phylogenetic tree, based on 16S rRNA gene sequences, showing the relationships between strains YIM

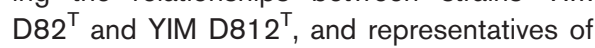
the family Rhodospirillaceae. Bootstrap percentages (based on 1000 replications) $>50 \%$ are shown at branch points. Filled circles indicate that the corresponding nodes were also recovered in the tree generated with the maximum-likelihood method. Bar, 0.01 substitutions per nucleotide position. 


\section{Description of Fodinicurvata gen. nov.}

Fodinicurvata (Fo.di.ni.cur.va'ta. L. fem. n. fodina mine; L. adj. curvatus -a -um curved; N.L. fem. n. Fodinicurvata curved-shaped bacterium isolated from a mine).

Cells are Gram-negative, facultatively anaerobic, nonmotile, vibrioid and rod-shaped. Catalase- and oxidasepositive. Bacteriochlorophyll $a$ is not detected. Accumulate PHB granules. Nitrate is reduced. The predominant polar lipids consist of diphosphatidylglycerol, phosphatidylmethylethanolamine and phosphatidylcholine. Phosphatidylinositol is variable among species. The DNA G +C content is $61.5-62.3 \mathrm{~mol} \%$. Member of the family Rhodospirillaceae. The type species is Fodinicurvata sediminis.

\section{Description of Fodinicurvata sediminis sp. nov.}

Fodinicurvata sediminis (sed.i.min' is. L. gen. n. sediminis of sediment).

Exhibits the following properties in addition to those given in the genus description. Colonies are cream-white, smooth, circular, convex and opaque, with slightly irregular margins. Cells are approximately $0.3-0.5 \mu \mathrm{m}$ wide and $0.7-1.5 \mu \mathrm{m}$ long. Temperature range for growth is $15-42{ }^{\circ} \mathrm{C}$ (optimum, $28{ }^{\circ} \mathrm{C}$ ). $\mathrm{pH}$ range for growth is 6.5-8.5 (optimum, 7.5). Grows at $\mathrm{NaCl}$ concentrations of $1.5-20 \%(\mathrm{w} / \mathrm{v})$. Positive for urease, arginine dihydrolase and nitrate reduction, and negative for hydrolysis of gelatin and aesculin, indole production, glucose acidification, L-phenylalanine deaminase and $\beta$-galactosidase. Utilizes L-arabinose, $\alpha$-cyclodextrin, $\mathrm{D}-$ glucose, maltose, D-mannitol, D-sorbitol, sucrose, D-xylose, ethanol, glycerol, acetate, citrate, L-asparagine, L-aspartic acid, L-glutamic acid and L-proline as sole carbon sources, but not adonitol, amylum, D-cellulose, $\beta$-cyclodextrin, dextrin, Lfructose, D-galactose, myo-inositol, D-lactose, D-mannose, melibiose, methanol, raffinose, L-rhamnose, D-ribose, trehalose, glycine, L-histidine, L-ornithine, L-phenylalanine or Dserine. With the API ZYM system, positive for alkaline phosphatase, esterase (C4), esterase lipase (C8), lipase (C14), leucine arylamidase, valine arylamidase, cystine arylamidase and trypsin, weakly positive for $\alpha$-chymotrypsin and naphthol-AS-BI-phosphohydrolase and negative for acid phosphatase, $\alpha$-galactosidase, $\beta$-galactosidase, $\beta$-glucuronidase, $\alpha$-glucosidase, $\beta$-glucosidase, $N$-acetyl- $\beta$-glucosaminidase, $\alpha$-mannosidase and $\alpha$-fucosidase. Sensitive to ( $\mu \mathrm{g}$ per disc, unless indicated otherwise): ampicillin (10), carbenicillin (100), chloramphenicol (30), erythromycin (15), penicillin (10 U) and streptomycin (10), and resistant to amikacin (30), gentamicin (10), nalidixic acid (30) and norfloxacin (10). Polar lipids consist of diphosphatidylglycerol, phosphatidylmethylethanolamine, phosphatidylcholine and one unknown phospholipid. Major fatty acids are $\mathrm{C}_{18: 1} \omega 7 c, \mathrm{C}_{18: 1} 2-\mathrm{OH}$ and $\mathrm{C}_{16: 0}$. The isoprenoid quinone is $\mathrm{Q}-10$. The DNA G+C content of the type strain is $61.5 \mathrm{~mol} \%$.

The type strain, YIM D82 ${ }^{\mathrm{T}}\left(=\mathrm{DSM} \quad 21159^{\mathrm{T}}=\mathrm{KCTC}\right.$ $\left.22351^{\mathrm{T}}\right)$, was isolated from the Fenggang salt mine in Yunnan, south-west China.

\section{Description of Fodinicurvata fenggangensis sp. nov.}

Fodinicurvata fenggangensis (feng.gang.en'sis. N.L. fem. adj. fenggangensis the locality of the salt mine from which the organism was isolated).

Exhibits the following properties in addition to those given in the genus description. Colonies are cream-white, smooth, circular, convex and opaque with slightly irregular margins. Cells are approximately $0.2-0.5 \mu \mathrm{m}$ wide and $0.5-$ $1.3 \mu \mathrm{m}$ long. Temperature range for growth is $15-42{ }^{\circ} \mathrm{C}$ (optimum, $28{ }^{\circ} \mathrm{C}$ ). $\mathrm{pH}$ range for growth is 6.5-8.5 (optimum, 7.5). Grows at $\mathrm{NaCl}$ concentrations of 1.5$20 \%(\mathrm{w} / \mathrm{v})$. Positive for urease, arginine dihydrolase and nitrate reduction, and negative for hydrolysis of aesculin and gelatin, indole production, glucose acidification, Lphenylalanine deaminase and $\beta$-galactosidase. Utilizes glucose, myo-inositol, maltose, citrate, L-asparagine, Laspartic acid, L-glutamic acid, glycerol and L-proline as sole carbon sources, but not adonitol, amylum, L-arabinose, Dcellulose, $\alpha$-cyclodextrin, $\beta$-cyclodextrin, dextrin, L-fructose, D-galactose, D-lactose, D-mannose, melibiose, raffinose, L-rhamnose, D-ribose, sucrose, trehalose, ethanol, Dmannitol, methanol, acetate, glycine, L-histidine, Lornithine, L-phenylalanine or D-serine. With the API ZYM system, positive for alkaline phosphatase, esterase lipase (C8), lipase (C14), leucine arylamidase, valine arylamidase, cystine arylamidase and naphthol-AS-BIphosphohydrolase, weakly positive for esterase (C4) and $\alpha$-chymotrypsin, and negative for acid phosphatase, trypsin, $\alpha$-galactosidase, $\beta$-galactosidase, $\beta$-glucuronidase, $\alpha$-glucosidase, $\beta$-glucosidase, $N$-acetyl- $\beta$-glucosaminidase, $\alpha$-mannosidase and $\alpha$-fucosidase. Sensitive to ( $\mu$ g per disc, unless indicated otherwise): carbenicillin (100), chloramphenicol (30) and penicillin (10 U), but resistant to amikacin (30), ampicillin (10), erythromycin (15), gentamicin (10), nalidixic acid (30), norfloxacin (10) and streptomycin (10). Polar lipids consist of diphosphatidylglycerol, phosphatidylmethylethanolamine, phosphatidylcholine, phosphatidylinositol and three unknown phospholipids. Major fatty acids are $\mathrm{C}_{18: 1} \omega 7 c, \mathrm{C}_{18: 1} 2$ $\mathrm{OH}$ and $\mathrm{C}_{16: 0}$. The isoprenoid quinone is $\mathrm{Q}-10$. The DNA $\mathrm{G}+\mathrm{C}$ content of the type strain is $62.3 \mathrm{~mol} \%$.

The type strain, YIM D812 ${ }^{\mathrm{T}}\left(=\right.$ CCTCC AA $208037^{\mathrm{T}}=\mathrm{DSM}$ $21160^{\mathrm{T}}$ ), was isolated from a salt mine of Fenggang in Yunnan, south-west China.

\section{Acknowledgements}

This work was supported by grants from the National Natural Science Foundation of China (NSFC) (30860013, 30460004, 30660004, 30760006), the Ministry of Science and Technology of China (863 Program, no. 2007AA021306), the Yunnan Provincial Sciences and Technology Department (2005PY01-1, 2006C0006M, 2009DA002) and Yunnan University (2008YB005). We are grateful to Mr Wei Chen for his help during sampling, as well as Ms Xiang-Feng Cai for her excellent technical assistance. 


\section{References}

Allgaier, M., Uphoff, H., Feelske, A. \& Wagner-Döbler, I. (2003). Aerobic anoxygenic photosynthesis in Roseobacter clade bacteria from diverse marine habitats. Appl Environ Microbiol 69, 5051-5059.

Altschul, S. F., Gish, W., Miller, W., Myers, E. W. \& Lipman, D. J. (1990). Basic local alignment search tool. J Mol Biol 215, 403-410.

Cho, J. C. \& Giovannoni, S. J. (2006). Pelagibaca bermudensis gen. nov., sp. nov., a novel marine bacterium within the Roseobacter clade in the order Rhodobacterales. Int J Syst Evol Microbiol 56, 855-859.

Coenye, T., Goris, J., Spilker, T., Vandamme, P. \& LiPuma, J. J. (2002). Characterization of unusual bacteria isolated from respiratory secretions of cystic fibrosis patients and description of Inquilinus limosus gen. nov., sp. nov. J Clin Microbiol 40, 2062-2069.

Cohen-Bazire, G., Sistrom, W. R. \& Stanier, R. Y. (1957). Kinetic studies of pigment synthesis by nonsulfur purple bacteria. J Cell Comp Physiol 49, 25-68.

Collins, M. D. \& Jones, D. (1980). Lipids in the classification and identification of coryneform bacteria containing peptidoglycans based on 2,4-diaminobutyric acid. J Appl Bacteriol 48, 459-470.

Collins, M. D., Pirouz, T., Goodfellow, M. \& Minnikin, D. E. (1977). Distribution of menaquinones in actinomycetes and corynebacteria. J Gen Microbiol 100, 221-230.

Cui, X.-L., Mao, P.-H., Zeng, M., Li, W.-J., Zhang, L.-P., Xu, L.-H. \& Jiang, C.-L. (2001). Streptomonospora salina gen. nov., sp. nov., a new member of the family Nocardiopsaceae. Int J Syst Evol Microbiol 51, 357-363.

Eckert, B., Weber, O. B., Kirchhof, G., Halbritter, A., Stoffels, M. \& Hartmann, A. (2001). Azospirillum doebereinerae sp. nov., a nitrogenfixing bacterium associated with the C4-grass Miscanthus. Int J Syst Evol Microbiol 51, 17-26.

Ezaki, T., Hashimoto, Y. \& Yabuuchi, E. (1989). Fluorometric deoxyribonucleic acid-deoxyribonucleic acid hybridization in microdilution wells as an alternative to membrane filter hybridization in which radioisotopes are used to determine genetic relatedness among bacterial strains. Int J Syst Bacteriol 39, 224-229.

Favinger, J., Stadtwald, R. \& Howard, G. (1989). Rhodospirillum centenum, sp. nov., a thermotolerant cyst-forming anoxygenic photosynthetic bacterium. Antonie Van Leeuwenhoek 55, 291-296.

Felsenstein, J. (1981). Evolutionary trees from DNA sequences: a maximum likelihood approach. J Mol Evol 17, 368-376.

Felsenstein, J. (1985). Confidence limits on phylogenies: an approach using the bootstrap. Evolution 39, 783-791.

Felsenstein, J. (1993). PHYLIP (phylogeny inference package), version 3.5c. Distributed by the author. Department of Genome Sciences, University of Washington, Seattle, USA.

Garrity, G. M., Bell, J. A. \& Lilburn, T. (2005). Family I. Rhodospirillaceae Pfennig and Trüper 1971, 17 ${ }^{\mathrm{AL}}$. In Bergey's Manual of Systematic Bacteriology, 2nd edn, vol. 2, The Proteobacteria, part C, The Alpha-, Beta-, Delta-, and Epsilonprotebacteria, pp. 1-40. Edited by D. J. Brenner, N. R. Krieg, J. T. Staley \& G. M. Garrity. New York: Springer.

Gregersen, T. (1978). Rapid method for distinction of Gram-negative from Gram-positive bacteria. Eur J Appl Microbiol Biotechnol 5, 123-127.

Imhoff, J. F., Petri, R. \& Suling, J. (1998). Reclassification of species of the spiral-shaped phototrophic purple non-sulfur bacteria of the $a$ Proteobacteria: description of the new genera Phaeospirillum gen. nov., Rhodovibrio gen. nov., Rhodothalassium gen. nov. and Roseospira gen. nov. as well as transfer of Rhodospirillum fulvum to Phaeospirillum fulvum comb. nov., of Rhodospirillum molischianum to Phaeospirillum molischianum comb. nov., of Rhodospirilium salinarum to
Rhodovibrio salinarum comb. nov., of Rhodospirillum sodomense to Rhodovibrio sodomensis comb. nov., of Rhodospirillum salexigens to Rhodothalassium salexigens comb. nov. and of Rhodospirillum mediosalinum to Roseospira mediosalina comb. nov. Int J Syst Bacteriol 48, 793-798.

Kawasaki, H., Hoshino, Y., Kuraiski, Y. \& Yamasato, K. (1992). Rhodocista centenaria gen. nov., sp. nov., a cyst-forming anoxygenic photosynthetic bacterium and its phylogenetic position in the Proteobacteria alpha group. J Gen Appl Microbiol 38, 541-551.

Khammas, K. M., Ageron, E., Grimont, P. A. D. \& Kaiser, P. (1989). Azospirillum irakense sp. nov., a nitrogen-fixing bacterium associated with rice roots and rhizosphere soil. Res Microbiol 140, 679-693.

Kimura, M. (1980). A simple method for estimating evolutionary rates of base substitutions through comparative studies of nucleotide sequences. J Mol Evol 16, 111-120.

Kovacs, N. (1956). Identification of Pseudomonas pyocyanea by oxidase reaction. Nature 178, 703-704.

Kumar, S., Tamura, K. \& Nei, M. (2004). MEGA3: integrated software for Molecular Evolutionary Genetics Analysis and sequence alignment. Brief Bioinform 5, 150-163.

Labrenz, M., Tindall, B. J., Lawson, P. A., Collins, M. D., Schumann, P. \& Hirsch, P. (2000). Staleya guttiformis gen. nov., sp. nov. and Sulfitobacter brevis sp. nov., $\alpha$-3-Proteobacteria from hypersaline, heliothermal and meromictic antarctic Ekho Lake. Int J Syst Evol Microbiol 50, 303-313.

Mack, E. E., Mandelco, L., Woese, C. R. \& Madigan, M. T. (1993). Rhodospirillum sodomense, sp. nov., a Dead Sea Rhodospirillum species. Arch Microbiol 160, 363-371.

Magee, C. M., Rodeheaver, G. \& Edgerton, R. F. (1975). A more reliable gram staining technique for diagnosis of surgical infections. Am J Surg 130, 341-346.

Maszenan, A. M., Seviour, R. J., Patel, B. K. C., Janssen, P. H. \& Wanner, J. (2005). Defluvicoccus vanus gen. nov., sp. nov., a novel Gram-negative coccus/coccobacillus in the 'Alphaproteobacteria' from activated sludge. Int J Syst Evol Microbiol 55, 2105-2111.

Mehnaz, S., Weselowski, B. \& Lazarovits, G. (2007a). Azospirillum canadense sp. nov., a nitrogen-fixing bacterium isolated from corn rhizosphere. Int J Syst Evol Microbiol 57, 620-624.

Mehnaz, S., Weselowski, B. \& Lazarovits, G. (2007b). Azospirillum zeae sp. nov., a diazotrophic bacterium isolated from rhizosphere soil of Zea mays. Int J Syst Evol Microbiol 57, 2805-2809.

Mesbah, M., Premachandran, U. \& Whitman, W. B. (1989). Precise measurement of the $\mathrm{G}+\mathrm{C}$ content of deoxyribonucleic acid by high-performance liquid chromatography. Int J Syst Bacteriol 39, 159-167.

Minnikin, D. E., O'Donnell, A. G., Goodfellow, M., Alderson, G., Athalye, M., Schaal, A. \& Parlett, J. H. (1984). An integrated procedure for the extraction of bacterial isoprenoid quinones and polar lipids. J Microbiol Methods 2, 233-241.

Nissen, H. \& Dundas, I. D. (1984). Rhodospirillum salinarum sp. nov., a halophilic photosynthetic bacterium isolated from a Portuguese saltern. Arch Microbiol 138, 251-256.

Peng, G., Wang, H., Zhang, G., Hou, W., Liu, Y., Wang, E. T. \& Tan, Z. (2006). Azospirillum melinis sp. nov., a group of diazotrophs isolated from tropical molasses grass. Int J Syst Evol Microbiol 56, 1263-1271.

Pfennig, N. \& Trüper, H. G. (1971). Higher taxa of the phototrophic bacteria. Int J Syst Bacteriol 21, 17-18.

Reinhold, B., Hurek, T., Fendrik, I., Pot, B., Gillis, M., Kersters, K., Thielemans, S. \& De Ley, J. (1987). Azospirillum halopraeferens sp. nov., a nitrogen-fixing organism associated with roots of Kallar Grass (Leptochloa fusca (L.) Kunth). Int J Syst Bacteriol 37, 43-51. 
Richard, C. \& Kiredjian, M. (1995). Laboratory Methods for the Identification of Strictly Aerobic Gram-negative Bacilli. Paris: Institut Pasteur.

Saitou, N. \& Nei, M. (1987). The neighbor-joining method: a new method for reconstructing phylogenetic trees. Mol Biol Evol 4, 406-425.

Sasser, M. (1990). Identification of bacteria by gas chromatography of cellular fatty acids. USFCC Newsl 20, 16.

Shi, B. H., Arunpairojana, V., Palakawong, S. \& Yokota, A. (2002). Tistrella mobilis gen. nov., sp. nov., a novel polyhydroxyalkanoate producing bacterium belonging to a-Proteobacteria. J Gen Appl Microbiol 48, 335-343.

Sly, L. I. \& Stackebrandt, E. (1999). Description of Skermanella parooensis gen. nov., sp. nov. to accommodate Conglomeromonas largomobilis subsp. parooensis following the transfer of Conglomeromonas largomobilis subsp. largomobilis to the genus Azospirillum. Int J Syst Bacteriol 49, 541-544.

Smibert, R. M. \& Krieg, N. R. (1994). Phenotypic characterization. In Methods for General and Molecular Bacteriology, pp. 607-654. Edited by P. Gerhardt, R. G. E. Murray, W. A. Wood \& N. R. Krieg. Washington, DC: American Society for Microbiology.
Tamaoka, J., Katayama-Fujimura, Y. \& Kuraishi, H. (1983). Analysis of bacterial menaquinone mixtures by high performance liquid chromatography. J Appl Bacteriol 54, 31-36.

Tarrand, J. J., Krieg, N. R. \& Döbereiner, J. (1978). A taxonomic study of the Spirillum lipoferum group, with description of a new genus, Azospirillum gen. nov., and two species, Azospirillum lipoferum (Beijerinck) comb. nov., and Azospirillum brasilense sp. nov. Can J Microbiol 24, 967-980.

Xie, C.-H. \& Yokota, A. (2005). Azospirillum oryzae sp. nov., a nitrogen-fixing bacterium isolated from the roots of the rice plant Oryza sativa. Int J Syst Evol Microbiol 55, 1435-1438.

Young, C. C., Hupfer, H., Siering, C., Ho, M.-J., Arun, A. B., Lai, W.-A., Rekha, P. D., Shen, F.-T., Hung, M.-H. \& other authors (2008). Azospirillum rugosum sp. nov., isolated from oil-contaminated soil. Int J Syst Evol Microbiol 58, 959-963.

Zhang, D., Yang, H., Zhang, W., Huang, Z. \& Liu, S.-J. (2003). Rhodocista pekingensis sp. nov., a cyst-forming phototrophic bacterium from a municipal wastewater treatment plant. Int J Syst Evol Microbiol 53, 1111-1114.

Zhang, G. I., Hwang, C. Y. \& Cho, B. C. (2008). Thalassobaculum litoreum gen. nov., sp. nov., a member of the family Rhodospirillaceae isolated from coastal seawater. Int J Syst Evol Microbiol 58, 479-485. 